\title{
Institutional Issues around Agricultural Land-Use Control for Groundwater Conservation-A Long-Term Perspective
}

\author{
Stephen Foster ${ }^{1,2, *(D)}$ and John Chilton ${ }^{3}$ \\ 1 Department of Earth Sciences, University College London, London WC1E-6BT, UK \\ 2 Groundwater Management Group, International Water Association, London E14-2BA, UK \\ 3 International Association of Hydrogeologists, Reading RG8-6BJ, UK; johnchilton48@gmail.com \\ * Correspondence: DrStephenFoster@aol.com
}

check for

updates

Citation: Foster, S.; Chilton, J.

Institutional Issues around

Agricultural Land-Use Control for

Groundwater Conservation-A

Long-Term Perspective. Water 2021,

13, 2417. https://doi.org/

10.3390/w13172417

Academic Editor: Maurizio Polemio

Received: 16 July 2021

Accepted: 27 August 2021

Published: 2 September 2021

Publisher's Note: MDPI stays neutral with regard to jurisdictional claims in published maps and institutional affiliations.

Copyright: (c) 2021 by the authors. Licensee MDPI, Basel, Switzerland. This article is an open access article distributed under the terms and conditions of the Creative Commons Attribution (CC BY) license (https:// creativecommons.org/licenses/by/ $4.0 /)$.
Abstract: Key aspects of policy development and implementation for the control of agricultural land use to conserve groundwater are overviewed. This is one of today's greatest environmental challenges and one on which only limited progress has been made internationally. For this purpose, the objectives of agricultural land-use control in defined areas are either to reduce diffuse pollution of groundwater and/or to regulate excessive abstraction for crop irrigation to sustain groundwater resources. Progress on both of these fronts has been assessed from the published work, and the lessons learnt are summarised for global application.

Keywords: groundwater management; groundwater protection; agricultural land use; diffuse agricultural pollution; groundwater over-exploitation

\section{Scope of Paper}

Land-use practices in aquifer recharge areas exert major influences on the quantity and quality of groundwater recharge and can indeed be the predominant control. Thus, agricultural land-use control is required in specifically defined areas to reduce both diffuse pollution of groundwater and/or excessive groundwater abstraction for crop irrigation. The institutional progress made and the impediments experienced with the implementation of policies to achieve the required level of land-use control to conserve groundwater are reviewed from published work (mainly from European, American and some Asian cases) and discussed to provide insights of global application.

\section{Diffuse Groundwater Pollution Control}

\subsection{Problem Definition}

Every land-use practice has a direct 'water resource footprint'. Their cumulative impact can generate an unacceptable contaminant load to groundwater on a widespread basis geographically and dominate groundwater quality. Concern over increasing groundwater nitrate pollution from agricultural practices has been voiced on a very widespread basis-including England [1], the USA [2], Spain [3] and China [4]. Similar concern has been expressed with regard to pesticide pollution [5-7].

In England, intensification of rainfed cereal production on thin Chalk downland soils in the counties of Cambridgeshire, Norfolk, Lincolnshire and East Yorkshire from the 1950s involved the ploughing up of grassland together with large increases in application of nitrogen fertiliser. The impact on Chalk groundwater became manifest by the mid-1970s [8], but it took about 15 years of further research before agricultural soil scientists and their ministry counterparts accepted the evidence, and the impacts are long-lasting and costly to remediate. This is well illustrated by the evolution of groundwater nitrate in the East Yorkshire Chalk over a period of more than 50 years (Figure 1), which has rainfall recharge of $240-280 \mathrm{~mm} / \mathrm{a}$ and historic soil leaching of $40-70 \mathrm{kgN} / \mathrm{ha} / \mathrm{a}$. Groundwater nitrate 
concentrations are still rising in some English areas (on average at $0.4 \mathrm{mgNO}_{3} / \mathrm{L} /$ year) but are expected to peak before 2025 [9].

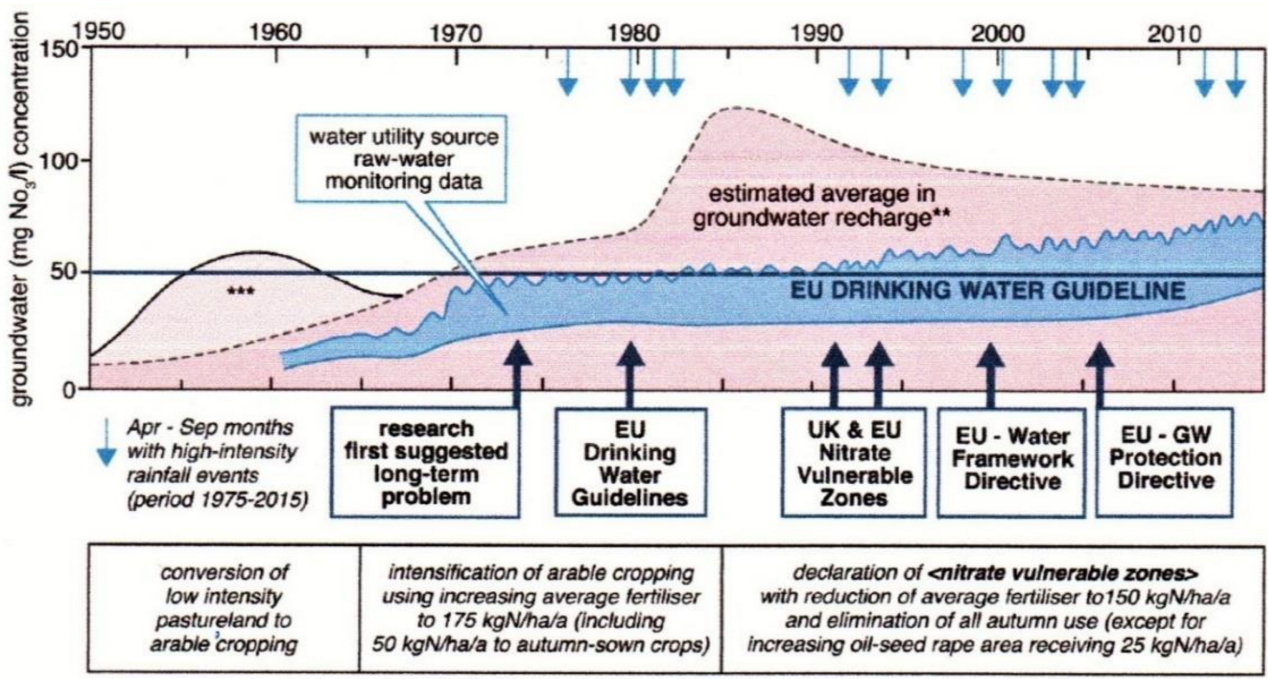

Figure 1. Evolution of land-use, groundwater nitrate and management measures in the East Yorkshire Chalk, United Kingdom. (** using (a) estimates of cropped area from 1980 as winter-wheat 45\%, winter-barley $15 \%$, oil-seed rape $15 \%$, spring-barley $15 \%$ and uncropped land $15 \%$. (b) Fertiliser $\mathrm{N}$ usage survey data distinguishing readily leached autumn dressings from spring dressings only leached by very exceptional rainfall events. ${ }^{* * *}$ very approximate estimate of leaching following initial ploughing-in of pasture land).

Pesticide contamination from both arable farming practices and non-agricultural uses has also occurred, with various compounds being detected in English groundwaters, some in excess of the stringent $0.1 \mu \mathrm{g} / \mathrm{L}$ level set by the EU Drinking Water Directive $[5,10,11]$. Pesticides and their metabolites have also been widely observed in US groundwaters [12-14].

Arable farming under minimal tillage in temperate climates requires large applications of herbicides, many of which degrade very slowly in groundwater systems compared to agricultural soils [10]. Moreover, increased use of fertilisers stimulates weed growth and makes plants more vulnerable to pathogens, which in turn often results in additional use of herbicides and fungicides [15]. The most common pesticide residues in English groundwaters are atrazine and simazine and their metabolites, which have also been heavily used in non-agricultural weed control (on roads, car parks, railways and airfields). The process of UK National Pesticide Registration offered the possibility of prohibiting the sale of toxic compounds, which are exceptionally mobile and persistent in groundwater, and atrazine and simazine were banned for non-agricultural and agricultural use, respectively, in 1993 and 2005.

The economic impact of agricultural pollution is substantial. Groundwater pollution by nitrate and pesticides cost the English water industry more than UK£700 million between 1975 and 2005 for capital works on replacement water supplies, treatment plants and engineering the blending high and low nitrate water. All the costs had to be borne by the water consumer. In the Seine Basin of France, more than 80 groundwater abstraction sites have been closed since 2007 because of high groundwater pesticide concentrations [15].

\subsection{Policy Development}

Pollution from a clearly defined point source can be controlled by environmental regulation (not considered here). In contrast, diffuse pollution can only be addressed by institutional action but requires sound agricultural and hydrogeological science as a basis for the development and implementation of policies that constrain agriculture in specific areas. Such policies usually involve differential land-use controls in areas defined 
by relative groundwater pollution risk and are guided by the mapping of aquifer pollution vulnerability and/or the delineation of the capture zones of potable water-supply wells.

Aquifer pollution vulnerability represents the degree of natural protection provided by the contaminant attenuation capacity of soil and the unsaturated zone above an aquifer. Pollution vulnerability mapping is a technique dating back to the late 1980s and has extensive published literature internationally [16-18]. The effectiveness of the physicochemical processes involved (filtration, adsorption, biodegradation and hydrolysis) varies with soil and rock structure, clay and organic matter content, and $\mathrm{pH}$. Thicker and less permeable unsaturated zones allow more time for attenuation processes to occur.

The capture zones of water-supply wells are usually defined by numerical modelling of groundwater flow systems [19]. However, the need to convert modelled zones into on-the-ground field and farm boundaries (which may be disputed) means their effective translation into areas of diffuse pollution control has often proved difficult in practice.

Having identified the target land areas, the next step of policy development involves defining the required level of land-use intervention. Measures can include:

- Influencing the choice of crop type and cropping regime;

- Reducing or eliminating the use of agrochemicals (fertilisers and/or pesticides) or controlling the timing of their use;

- Generally moving to less intensive agricultural production or non-agricultural land uses.

The resulting measures can either be applied in a moderate way to the entire vulnerable area or more strongly in the restricted area of the water-supply capture zone. In the former case, policies are normally implemented by an agricultural ministry or advisory agency, working in collaboration with the environment or water-resource agency. In the case of water well capture zones, the lead is often taken by the corresponding water utility in negotiation with specific local farmers, commonly under some form of compensatory payment scheme.

An example of the former is provided by the EU Nitrate Directive (1991), which required the declaration of Nitrate Vulnerable Zones (NVZs) covering most of the extensive areas of aquifer recharge. In England, numerous measures were recommended in such zones as 'best agricultural practice' to reduce nitrate leaching, including the elimination of $\mathrm{N}$ fertiliser applications to autumn-sown crops, direct drilling for sowing seeds to reduce soil $\mathrm{N}$ oxidation, the promotion of autumn (rather than spring) sown crops and growing 'winter cover crops' to reduce leaching losses. Nevertheless, without more radical land-use changes, such measures are not sufficient to reduce average recharge quality to less than $50 \mathrm{mgNO}_{3} / \mathrm{L}$ [20]. Such major changes in agricultural land use would have to include moves towards organic farming and low-intensity grazing [21].

In England, an example of more locally focused controls in response to the EU Nitrate Directive was Nitrate Sensitive Areas (NSAs). This was a voluntary scheme in place between 1990 and 2003 that aimed to reduce nitrate leaching by modifying land-use management within water-supply catchment zones with compensation payments to farmers, including conversion of some areas to rough pasture or coppice woodland. Measurements from 22 NSAs introduced in 1994-1995 showed an average 34\% decrease in the nitrate concentration of water leaching from the soils (from $115 \mathrm{mg} / \mathrm{L}$ in $1995-1996$ to $76 \mathrm{mg} / \mathrm{L}$ in 1998-1999 [22]. The study looked at two NSAs in considerable detail-Old Chalford, an $81 \mathrm{~km}^{2}$ catchment with shallow water-table in the Jurassic Limestone of Oxfordshire and Pollington, a $358 \mathrm{~km}^{2}$ catchment with three public water-supply sources on the Triassic Sherwood Sandstone of North Yorkshire. At Old Chalford, reductions in nitrate soil had a measurable effect at public-supply abstraction points after only 2 years. In contrast, at Pollington, there was little beneficial effect of the measures on abstracted groundwater quality during the study, with a noticeable impact predicted only after 30 years [22]. As a consequence of such time-lags in groundwater response, the institutional and political commitment to the 'compensation approach' could not be maintained, and NSAs were incorporated into the broader and less stringent NVZ scheme. 


\subsection{Institutional Obstacles to Policy Implementation}

The challenge of controlling agricultural land-use practices for groundwater quality protection is primarily of an institutional rather than technical character. In particular, it is influenced by the lack of clear incentives for key players to act at the appropriate level and over the required area for a problem that falls only partly in their domain. For example, there is an absence of clear incentives or definite obligations for farmers to act in the interest of protecting groundwater quality without a legal and economic partnership with the local water-resource regulator or water utility.

The basic principles of groundwater protection suggest that the 'potential polluter should meet the cost of putting protection measures into practice', but this remains problematic since the best examples of effective action are where water utilities have underwritten the costs of modifying land-cultivation regimes to favour higher-quality groundwater recharge in public water well capture zones [23-26].

Actions by environmental or water-resource agencies cannot normally go as far as requiring land-use changes and are restricted to advocating practices to the agricultural ministry that:

- Reduce nutrient leaching losses from existing cropping practices;

- Ban the sale of a given pesticide because of its high mobility and persistence.

While a step in the right direction, such actions are not on their own capable of ensuring potable quality groundwater recharge $[27,28]$. The slow reaction of groundwater systems to external changes means that the benefits of land-use management for groundwater quality are also much delayed and tend to fall outside the timeframe of democratic governments.

In comparing the response to agricultural nitrate pollution in Poland and Denmark, numerous 'enabling and constraining factors' were identified [29] that affected the ability to meet the obligations of the EU Nitrate Directive and Water Framework Directive (WFD) fully. Research in two areas of Poland identified the enabling factors as:

- The legal framework of these directives with its devolution of power to local levels;

- Good communication with farmers and a general acceptance that nitrate pollution from agricultures needs to be addressed.

Meanwhile, the constraining factors included:

- A mismatch of responsibilities between agencies, leading to a lack of cooperation and competing policy priorities;

- A notable lack of financial and staff resources for implementation;

- Fragmented farming with a high level of political power in the farming community.

Such institutional constraints are likely to be experienced widely, and the political power of farmers, in particular, was also noted in the Seine Basin [15].

A recent review of the lessons learnt from EU-WFD implementation in England and Scotland [30] concluded that the joined-up governance structure in Scotland enabled policy-makers and interest groups to work together to build cooperation and facilitated the adoption of stricter measures for tackling diffuse pollution. In contrast, greater institutional fragmentation in England lessened the engagement of all parties and acted as a barrier to cooperation.

In many countries, there is a lack of clear incentive for water utilities to take action on groundwater quality protection through land-use controls because of the uncertainty of the success of the approach and the time taken for the beneficial impacts of controls to be realised. It is often perceived by utilities as more secure to achieve drinking-water quality goals by complex water treatment, which is completely under water-utility control and whose capital and operating costs can be charged to water users. This is despite the fact that it directly contravenes the EU-WFD and Groundwater Directive, which clearly advocate that:

- Advanced water treatment to meet drinking-water quality should be avoided;

- Environmental degradation should be rectified at source; 
- Costs should be borne by the polluter [31].

This approach also embraces the general objective of the EU precautionary principle that preventive action should be taken wherever possible. The EU-WFD thus promotes a shift from traditional end-of-pipe solutions towards sustainable catchment management.

Managing diffuse pollution often requires strengthened coherence between policies in different sectors. Agricultural policy and the economic benefits of farming may encourage greater productivity, whereas environmental policy is likely to emphasise resource conservation. At the national or sub-national level, this can produce significant institutional impediments to controlling diffuse pollution. At the European level, there has long been concern about the potentially conflicting objectives of the EU-WFD and the EU Common Agricultural Policy (CAP) [32]. To improve coherence, a 'cross-compliance mechanism' was aimed at linking some CAP payments with environmental requirements. In the newest CAP provisions, which came into effect in 2020, cross-compliance is replaced by 'conditionality', linking income support to environment-friendly and climate-friendly farming practices and standards [15].

\section{Groundwater Resource Conservation}

\subsection{Nature of Concerns}

The last 30-40 years have witnessed massive increases in the use of groundwater for irrigation, especially in areas subject to extended dry seasons and/or regular droughts, making a major contribution to food production and improving the livelihoods of millions of smallholder farmers $[33,34]$. Groundwater is a very popular commodity with farmers, given that it is usually found close to the point of use, developed quickly at low capital cost and is available directly on demand at the times of crop water need. Amongst the countries with the greatest use of groundwater irrigation are India, China, Pakistan, Mexico, the USA, Australia and Spain. Today irrigated agriculture is the largest abstractor and consumer of groundwater resources, with around $40 \%$ of all cultivated land under irrigation being water well equipped [35].

Since the land usable for cultivation usually exceeds the water available for crop irrigation, and most water well development has occurred through the private investment of small farmers, it has largely been unregulated and widely resulted in excessive groundwater abstraction from both shallow and deep aquifers [36]. Consequences include serious depletion of groundwater reserves, shallow water wells running dry, groundwater pumping costs increasing, wetlands drying out and dry-weather streamflows declining. The side-effects have also compromised the continuity of human potable water supply, which is the most critical groundwater function (although of more modest demand volumetrically than irrigation). Moreover, poor-quality irrigation returns to shallow aquifers can have seriously negative environmental impacts [37]. Even in temperate humid climates, intensive groundwater abstraction can lead to short-term aquifer depletion during drought, significantly impacting groundwater-dependent ecosystems.

In semi-arid Spain, regulatory powers exist to counteract excessive groundwater abstraction, but there are various examples of serious resource overexploitation for irrigated agriculture. Caps on maximum licensed groundwater use can be reinforced by levying abstraction fees. However, for several decades the aquifers of South-Eastern Spain have been very heavily developed for intensive irrigated agriculture [38], and groundwater overexploitation is a major challenge for the Segura and Guadalquivir Basin Agencies. There have been water-level depletions of 100-300 m or more in the basins of Vinalopo (Alicante), Guadalentin and Campo de Cartagena (Murcia) (Figure 2) and Campo de Nijar (Almeria) as a result of over-exploitation at rates of 2-4 times the average annual recharge [39]. The transfer of surplus surface-water (Figure 2), wastewater reclamation and brackish-water desalination at a range of scales has been introduced to alleviate the problem, but a return to hydrogeologic equilibrium is unlikely to be economically feasible even in the long term [27]. In some cases, aquifers are, in practice, being treated as 'only 
suitable for agricultural use' and alternative water sources developed for public water supply with the costs being charged to society.

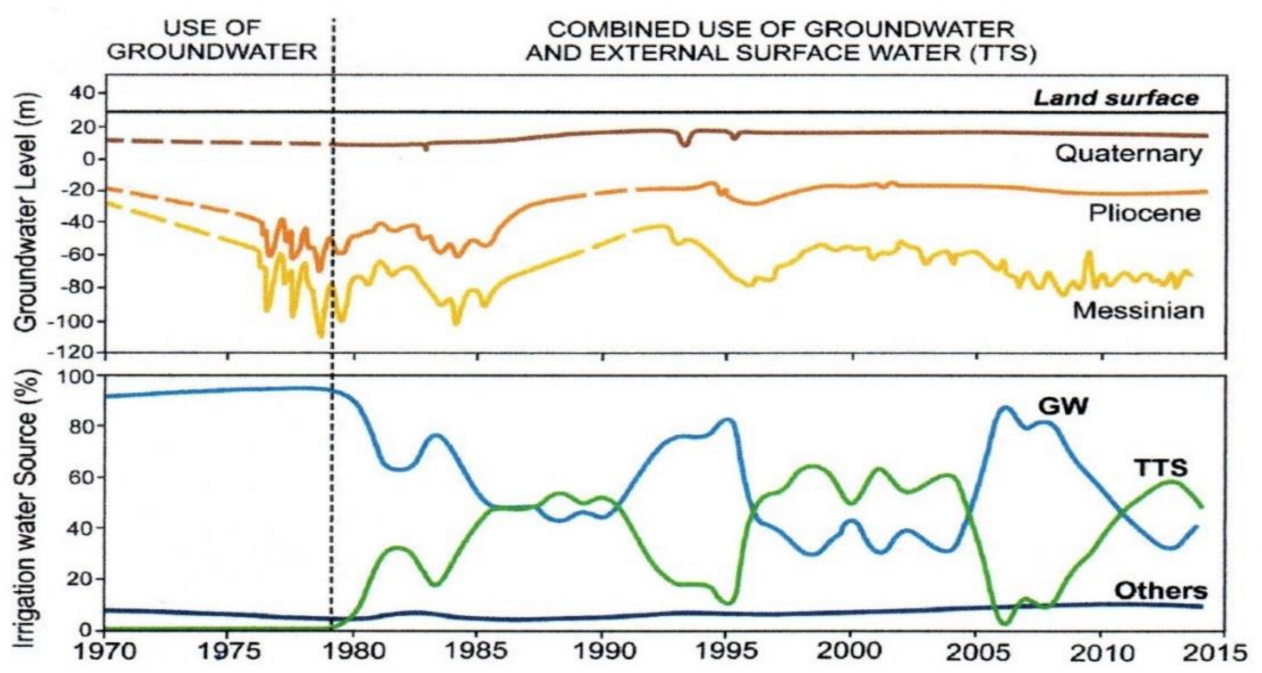

Figure 2. Evolution of groundwater levels with irrigation-water source in layered Campo de Cartagena aquifer system (Murcia) Spain. GW-local groundwater resources; TTS-surface-water transfer from the Tajo to Segura basin.

In the USA, about $60 \%$ of agriculture relies on groundwater for irrigation, with a total pumping of about $100 \mathrm{~km}^{3}$ /year from some 0.2 million water wells. The major aquifers of the High Plains and the California Central Valley have long been seriously overexploited [40], and declining water well yields are likely to produce significant reductions in food production in the medium term.

In India, the groundwater-irrigated area has increased by more than $500 \%$ since 1960 and amounted to about $200 \mathrm{~km}^{3}$ /year on 39 Mha in 2010 with around $20 \mathrm{M}$ irrigation water wells. Demand was driven by rural-population pressure making more intensive land use (with a second and sometimes third crop) imperative and further stimulated by grants and loans for water well construction and widespread rural electrification with, in many cases, highly subsidised electrical energy for water well pumps [41]. Groundwater irrigation is concentrated in western and peninsula India (states of Punjab, Haryana, Karnataka. Andhra Pradesh, Gujurat, Tamil Nadu and Uttar Pradesh).

\subsection{Key Actions for Sustainable Management}

The most direct way of reducing water well abstraction from an aquifer system is to reduce the irrigated area substantially. This is usually achieved by leaving tracts of land fallow for one growing season or cultivating a lower-value rainfed crop, and the environment or water-resource regulator can monitor compliance effectively using remote sensing techniques. However, deploying land-use change directly to control groundwater abstraction or stricter enforcement of groundwater-use rights to reduce irrigation-water availability implies a high level of institutional regulatory capacity and has only proved possible in some exceptional circumstances.

The groundwater resources of the North China Plain are seriously overexploited as a result of water well irrigation for the ubiquitous winter-wheat crop [42]. It is estimated that the local water resource bureau will need to reduce the extension of winter wheat on this large land area by about $30 \%$, substituting a lower-value rainfed crop or leaving the land fallow. However, compensation payments at rates equivalent to about US $\$ 1200 /$ ha /year to the farmers involved will be required, which is clearly impeding the rate of implementation [43].

A similar approach has been implemented successfully over a much smaller land area in Mendoza, Argentina, to protect against increasing groundwater salinisation, but in this 
case by enforcing adherence to previously agreed individual water rights and without any payment of compensation [44].

If excessive groundwater exploitation is to be confronted, integrated responses across the water/agriculture policy interface need to be defined, adopted and implemented. The main obstacles to effective groundwater policy are:

- That groundwater is to most an 'invisible resource' with much-delayed impacts;

- Perverse agricultural subsidies for water well construction, electrical energy for pumping and crop guarantee prices, which often stimulate irrigated agricultural production regardless of the status of groundwater resources;

- The costs and difficulty of measurement and inadequate monitoring of groundwater.

These obstacles must be confronted by agricultural and hydrogeological scientists and their corresponding sector administrators, but this may not be straightforward as a consequence of their different scales of field research (from aquifer system to experimental plot).

For the most part, the approach to the control of groundwater use for irrigation has to be adapted to the unique and complex set of socio-ecological and political conditions found in individual countries or provinces-'one size certainly cannot fit all circumstances' [45,46]. Land-use and crop changes are much more likely to be the outcome of groundwater management actions rather than the direct approach adopted. The diverse nature of the challenges means that a combination of measures will be needed, including:

- Groundwater governance and regulatory provisions, such as abstraction rules and caps, licenses and charges, and conservation zones;

- The promotion of conjunctive use of groundwater and surface-water for adaptive resource management;

- Land-user incentives for groundwater services through agri-environmental stewardship schemes and land ownership/leasing arrangements.

In turn, the effectiveness of all these measures will depend on the prevailing legal framework and political will, the level of stakeholder awareness on groundwater sustainability issues and the involvement of an informed and organised civil society with a clear long-term vision $[45,47]$.

The challenge of collective action is much greater in South Asia, with its millions of irrigation water wells, than in the USA, Mexico or Spain. However, despite the much lower number of people dependent on groundwater in these countries, there are strong farmer lobbies that create political pressure to resist change. Thus, in all cases, the first step must be to eliminate perverse agricultural subsidies, especially those reducing electrical energy costs for water well pumping, and charges for groundwater abstraction can generally best be levied jointly with those for electricity use. Both of these actions are in the direct control of national and local governments.

Groundwater resource conservation approaches that employ increased irrigation efficiency can offer the prospect of reduced groundwater abstraction, but without control over abstraction, the water thus saved will often be used to bring more of the available land under irrigated cultivation. It is now also recognised that improving so-called 'irrigationwater efficiency' on permeable soil profiles does not save groundwater resources, because almost all the 'losses' are in practice irrigation returns to groundwater [48], and more direct actions, such as reducing the cropped irrigated area, are required to reduce the consumptive use of groundwater resources.

To address the groundwater management challenge effectively, the corresponding local agencies need to be empowered by the central government to design appropriate control measures and conduct long-term monitoring, for which they will need to be:

- Empowered legally to address the control of groundwater abstraction and use;

- Adequately staffed (in terms of professional and support personnel) to cope with the regulation of large numbers of individually small groundwater users;

- Equipped at the executive level with understanding of the risks associated with excessive groundwater abstraction and the confusion surrounding irrigation efficiency; 
- Resourced financially to undertake the sort of detailed monitoring from which to make early predictions of adverse groundwater trends.

\section{Conclusions}

Water-resource regulators need to put more emphasis on protecting groundwater because of its special importance for drinking-water provision and sustaining certain aquatic ecosystems. A paradigm shift in water resource management is necessary to conserve groundwater in areas under pressure from intensive agriculture. In the EU, some significant progress has been made over various decades in:

- Raising awareness of the impact of human activities on the environment;

- Bringing together surface water and groundwater into a river basin approach to environmental management;

- Encouraging broader stakeholder involvement in conserving the environment;

- Elaborating 'best agricultural practice' guidelines that will reduce (but not eliminate) nitrate leaching rates to groundwater;

- Explicit consideration of pesticide mobility and persistence in groundwater systems during the product registration process to reduce groundwater pollution risk.

However, much remains to be done. Groundwater protection requirements need to be more widely incorporated into land-use planning, with zonal restrictions being imposed according to local conditions. The technical basis for the delineation of such zones (for resource preservation and quality protection) are now well established, but their application requires appropriate local evidence, administrative consistency and trained personnel, together with broad stakeholder acceptance.

In efforts to find the way forward in promoting the required control of agricultural land-use practices, certain impediments will need to be confronted, notably:

- Institutional-the relevant institutions (agriculture, water resources, environmental planning, municipal land-use administration and water-service utilities) often operate in separate 'silos', so it is essential to nurture collaboration, both horizontally between sectors and vertically between national and local level;

- Economic - the declaration of resource conservation zones often causes land-values with water well use-rights to rise sharply, often by $200-700 \%$ [38], and the water resource administration will need to resist pressure for illegal water well drilling, while in contrast, groundwater quality protection zones can have the reverse effect by lowering land values because productivity is reduced;

- Social-public awareness needs to be raised for effective policy implementation; otherwise, the 'public administration' will tend to opt for 'business as usual'.

Author Contributions: S.F. and J.C. undertook 65\% and 35\%, respectively, of the literature review for this paper. S.F. prepared the original draft manuscript with J.C. undertaking its systematic review and strengthening. All authors have read and agreed to the published version of the manuscript.

Funding: This research received no external funding.

Institutional Review Board Statement: The IRB Statement is not applicable to this work.

Informed Consent Statement: Informed consent was obtained from all subjects involved in the study.

Conflicts of Interest: The authors declare no conflict of interest.

\section{References}

1. Foster, S.S.D.; Cripps, A.C.; Smith-Carington, A. Nitrate leaching to groundwater. Philos. Trans. R. Soc. Lond. 1982, 296, 477-489.

2. Burow, K.R.; Nolan, B.T.; Rupert, M.G.; Dubrovsky, N.M. Nitrate in groundwater in the United States: 1991-2003. Environ. Sci. Technol. 2010, 44, 4988-4997. [CrossRef] [PubMed]

3. Gonzalez-Vasquez, J.C.; Grande, J.A.; Barragan, F.J.; Ocana, J.A.; De La Torre, M.L. Nitrate accumulation and other components of groundwater in relation to the cropping system in an aquifer of southwestern Spain. Water Resour. Manag. 2005, 19, 1-22.

4. Chen, J.; Tang, C.; Sakura, Y.; Yu, J. Nitrate pollution from agriculture in different hydrogeological zones of the groundwater flow system in the North China Plain. Hydrogeol. J. 2005, 13, 481-492. [CrossRef] 
5. Foster, S.S.D.; Chilton, P.J.; Stuart, M.E. Mechanisms of groundwater pollution by pesticides. J. Inst. Water Environ. Manag. 1991, 5, 186-193. [CrossRef]

6. Dolan, T.; Howsam, P.; Parsons, D.J.; Whelan, M.J. Impact of EU-Water Framework Directive Article 7 on drinking-water compliance for pesticides: Challenges of prevention-led approach. Water Policy 2014, 16, 280-297. [CrossRef]

7. Skevas, T. Evaluating alternative policies to reduce pesticide groundwater pollution in Dutch arable farming. J. Environ. Plan. Manag. 2020, 63, 733-750. [CrossRef]

8. Lawrence, A.R.; Foster, S.S.D.; Izzard, P.W. Nitrate pollution of Chalk groundwater in East Yorkshire-a decade on. J. Inst. Water Eng. Sci. 1983, 37, 410-419.

9. Stuart, M.E.; Chilton, P.J.; Kinniburgh, D.G.; Cooper, D.M. Screening for long-term trends in groundwater nitrate monitoring data. Q. J. Eng. Geol. Hydrogeol. 2007, 40,361-376. [CrossRef]

10. Chilton, P.J.; Stuart, M.E.; Gooddy, D.C.; Williams, R.J.; Johnson, A.C. Pesticide fate and behaviour in the Chalk aquifer and implications for groundwater quality. Q. J. Eng. Geol. Hydrogeol. 2005, 38, 65-81. [CrossRef]

11. Lapworth, D.J.; Goody, D.C. Source and persistence of pesticides in a semi-confined Chalk aquifer of South-East England. Environ. Pollut. 2006, 144, 1031-1044. [CrossRef]

12. Kolpin, D.W.; Barbash, J.E.; Gilliom, R.J. Occurrence of pesticides in shallow groundwater of the United States: Initial results from the National Water-Quality Assessment Program. Environ. Sci. Technol. 1998, 32, 558-566. [CrossRef]

13. Toccalino, P.L.; Gilliom, R.J.; Lindsey, B.D.; Rupert, M.G. Pesticides in groundwater of the United States: Decadal-scale changes during 1993-2011. Ground Water 2014, 52, 112-125. [CrossRef]

14. Bexfield, L.M.; Belitz, K.; Lindsey, B.D.; Toccalino, P.L.; Nowell, L.H. Pesticides and pesticide degradates in groundwater used for public supply across the United States: Occurrence and health context. Environ. Sci. Technol. 2020, 55, 362-372. [CrossRef]

15. Bouleau, G.; Barbier, R.; Halm-Lemeille, M.P.; Tassin, B.; Buchs, A.; Habets, F. Despite great expectations in the Seine River Basin, the EU-WFD did not reduce diffuse pollution. Water Altern. 2020, 13, 534-555.

16. Fadlelmawla, A.; Fayad, M.; El-Gamily, H.I.; Rashid, T. A land-surface zoning approach based on 3-component risk criteria for groundwater quality protection. Water Resour. Manag. 2011, 25, 1677-1697. [CrossRef]

17. Foster, S.; Hirata, R.; Andreo, B. The aquifer pollution vulnerability concept: Aid or impediment in promoting groundwater protection? Hydrogeol. J. 2013, 21, 1389-1392. [CrossRef]

18. Beloch, M.A.; Sahar, L. Development of a watershed-based geospatial groundwater specific vulnerability assessment tool. Ground Water 2014, 52, 137-147. [CrossRef] [PubMed]

19. Frind, E.O. Delineation of three-dimensional well capture zones for complex multi-aquifer systems. Ground Water 2002, 40, 586-598. [CrossRef] [PubMed]

20. Foster, S.S.D. Assessing and controlling the impacts of agriculture on groundwater-from barley barons to beef bans. Q. J. Eng. Geol. Hydrogeol. 2000, 33, 263-280. [CrossRef]

21. Garnier, J.; Ramarson, A.; Billen, G.; Théry, S.; Thiéry, D.; Thieu, V.; Minaudo, C.; Moatar, F. Nutrient inputs and hydrology together determine biogeochemical status of the Loire River (France): Current situation and possible future scenarios. Sci. Total Environ. 2018, 637, 609-624. [CrossRef] [PubMed]

22. Silgram, M.; Williams, A.; Waring, R.; Neumann, I.; Hughes, A.; Mansour, M.; Besien, T. Effectiveness of the Nitrate Sensitive Areas Scheme in reducing groundwater concentrations in England. Q. J. Eng. Geol. Hydrogeol. 2005, 38, 117-127. [CrossRef]

23. Foster, S.; Hirata, R.; Gomes, D.; D’Elia, M.; Paris, M. Groundwater Quality Protection-A Guide for Water Utilities, Municipal Authorities and Environment Agencies; World Bank Publication: Washington, DC, USA, 2002; 103p.

24. Grolleau, G.; McCann, L.M.J. Designing watershed programs to pay farmers for water-quality services: Case studies of Munich \& New York City. Ecol. Econ. 2012, 76, 87-94.

25. Barataud, F.; Aubry, C.; Wezel, A.; Mundler, P. Management of drinking water catchment areas in cooperation with agriculture and the specific role of organic farming: Experiences from Germany and France. Land Use Policy 2014, 36, 585-594. [CrossRef]

26. Thomsen, R.; Søndergaard, V.H.; Sørensen, K.I. Hydrological mapping as a basis for establishing site-specific groundwater protection zones in Denmark. Hydrogeol. J. 2014, 12, 550-562. [CrossRef]

27. Foster, S.; Custodio, E. Groundwater resources and intensive agriculture in Europe-can regulatory agencies cope with the threat to sustainability? Water Resour. Manag. 2019, 33, 2139-2151. [CrossRef]

28. Boezeman, D.; Wiering, M.; Crabbé, A. Agricultural diffuse pollution and the EU-Water Framework Directive: Problems and progress in governance. Water 2020, 12, 2590. [CrossRef]

29. Ptak, E.N.; Graversgaard, M.; Refsgaard, J.C.; Dalgaard, T. Nitrate management discourses in Poland and Denmark-laggards or leaders in water quality protection. Water 2020, 12, 2371. [CrossRef]

30. De Vito, L.; Fairbrother, M.; Russel, D. Implementing the EU-Water Framework Directive and tackling diffuse pollution from agriculture: Lessons from England and Scotland. Water 2020, 12, 244. [CrossRef]

31. Wiering, M.; Boezeman, D.; Crabbé, A. The EU-Water Framework Directive and agricultural diffuse pollution: Fighting a running battle? Water 2020, 12, 1447. [CrossRef]

32. European Commission. A Blueprint to Safeguard Europe's Water Resources; EU-COM-2012: Brussels, Belgium, 2012.

33. Llamas, M.R.; Martinez-Santos, P. Intensive groundwater use: Silent revolution and potential source of social conflicts. ASCE J. Water Resour. Plan. Manag. 2005, 131, 337-341. [CrossRef]

34. Shah, T. Taming the Anarchy: Groundwater Governance in South Asia; Resources for Future Press: Washington, DC, USA, 2009. 
35. Siebert, S.; Burke, J.; Faures, J.M.; Frenken, K.; Hoogeveen, J.; Döll, P.; Portmann, F.T. Groundwater use for irrigation-A global inventory. Hydrol. Earth Syst. Sci. 2010, 14, 1863-1880. [CrossRef]

36. Foster, S.; Shah, T. Groundwater Resources and Irrigated Agriculture-Making a Beneficial Relation More Sustainable; GWP Perspectives Paper; Global Water Partnership: Stockholm, Sweden, 2012.

37. Foster, S.; Pulido-Bosch, A.; Vallejos, A.; Molina, L.; Llop, A.; MacDonald, A.M. Impact of irrigated agriculture on groundwaterrecharge salinity: A major sustainability concern in semi-arid regions. Hydrogeol. J. 2018, 26, 2781-2791. [CrossRef]

38. Garrido, A.; Martínez-Santos, P.; Llamas, M.R. Groundwater irrigation and its implications for water policy in semi-arid countries-The Spanish experience. Hydrogeol. J. 2006, 14, 340-349. [CrossRef]

39. Custodio, E.; Andreu-Rodes, J.M.; Aragón, R.; Estrela, T.; Ferrer, J.; García-Aróstegui, J.L.; Manzano, M.; Rodríguez-Hernández, L.; Sahuquillo, A.; Del Villar, A. Groundwater intensive use and mining in southeastern Spain: Hydrogeological, economic and social aspects. Sci. Total Environ. 2016, 559, 302-316. [CrossRef] [PubMed]

40. Scanlon, B.R.; Faunt, C.C.; Longuevergne, L.; Reedy, R.C.; Alley, W.M.; McGuire, V.L.; McMahon, P.B. Groundwater depletion and sustainability of irrigation in the US High Plains and Central Valley. Proc. Natl. Acad. Sci. USA 2012, 109, 9320-9325. [CrossRef]

41. Mukherji, A.; Shah, T. Groundwater socio-ecology and governance: A review of institutions and policies in selected countries. Hydrogeol. J. 2005, 13, 328-345. [CrossRef]

42. Foster, S.; Garduno, H.; Evans, R.; Olson, D.; Tian, Y.; Zhang, W.; Han, Z. Quaternary Aquifer of the North China Plain-Assessing and achieving groundwater resource sustainability. Hydrogeol. J. 2004, 12, 81-93. [CrossRef]

43. McLaughlin, D.; Kinzelbach, W. Food security and sustainable water-resources management. Water Resour. Res. 2015, 51, 017053. [CrossRef]

44. Foster, S.; Garduño, H. Integrated approaches to groundwater resource conservation in the Mendoza Aquifers of Argentina. GW-MATe Case Profile Collection 6. World Bank (Washington, DC) Sustainable Groundwater Management: Concepts \& Tools Series. 2006. Available online: www.un-igrac.org/groundwater-management (accessed on 2 August 2021).

45. Garduño, H.; Foster, S. Sustainable Groundwater Irrigation-Approaches to Reconciling Demand with Resources; GW-MATe Strategic Overview Series 4; World Bank: Washington, DC, USA, 2010.

46. Shah, T. Groundwater Governance and Irrigated Agriculture; GWP-TEC Background Paper 19; Global Water Partnership: Stockholm, Sweden, 2014.

47. Foster, S.; Steenbergen, F.; Zuleta, J.; Garduno, H. Conjunctive Use of Groundwater and Surface Water-From Spontaneous Coping Strategy to Adaptive Resource Management; GW-MATe Strategic Overview Series 2; World Bank: Washington, DC, USA, 2010.

48. Foster, S.; Perry, C. Improving groundwater resource accounting in irrigated areas: A prerequisite for promoting sustainable use. Hydrogeol. J. 2010, 18, 291-294. [CrossRef] 